\title{
Zbigniew Kubacki SI, Wprowadzenie do teologii religii, Seria Bobolanum nr 11, Wydawnictwo RHETOS, Warszawa 2018, ss. 307
}

Religia stanowiła i stanowi ważny komponent kultury. W rozumieniu filosię, w końcu ubogaca świat swojego ducha, staje odwiecznie wobec wartości: prawdy, dobra, piękna i świętości (sacrum). Ta ostatnia wartość oddziałuje na wszystkie wcześniejsze. Badania nad religią, która - mimo postępującej desakralizacji życia - wciąż odgrywa kluczową rolę zarówno w życiu jednostek, jak i społeczeństw („ludów i narodów”) nie straciły na aktualności.

Całość badań nad religią ma charakter interdyscyplinarny. W polskiej terminologii naukowej od dziesięcioleci żywa jest dążność, by nie tylko wprowadzić „W życie”, ale i upowszechnić oraz uzasadnić pojęcie „religiologii”, bądź „nauk religiologicznych". Religiologię, stanowiącą kompleks prac badawczych nad religią, stanowią trzy typy wiedzy o religii: szczegółowa, filozoficzna i teologiczna. Jako nauka kompleksowa religiologia składa się $\mathrm{z}$ autonomicznych dyscyplin badawczych o tym samym przedmiocie formalnym. Dyscyplinami tymi są: religioznawstwo, filozofia religii i teologia religii. Wyszczególnienie dziedzin religiologii koresponduje z różnymi sposobami poznawania rzeczywistości w ogóle (a zatem również religii). Religioznawstwo jest nauką empiryczną. Filozofia religii odwołuje się w swojej argumentacji do racji rozumowych. Posługuje się narzędziami wypracowanymi przez filozofię. Teologia religii, która sytuuje się „na granicy” teologii sensu stricte i religioznawstwa „przywołuje” w swojej argumentacji (bądź przynajmniej przywoływać powinna) przesłanki z objawienia Bożego.

Historycznie rzecz ujmując między teologią a naukami o religii istnieje szereg powiązań. Genezy tej nowej nauki, szczególnie rozwiniętej po II wojnie światowej, szukać należy u początków chrześcijaństwa. Kościół wówczas nie mógł nie podjąć kwestii swojego odniesienia do innych religii starożytnych (przedchrześcijańskich) oraz filozofii niechrześcijańskich, nie mających ściśle religijnego przesłania, czy w końcu mitologii. Ojcowie Kościoła stawiali pytanie

\footnotetext{
Eugeniusz SAKowiCz - e-mail: eugeniusz.sakowicz@wp.pl
} 
o możliwość objawienia poza chrześcijaństwem. Zwracali uwagę na istnienie zalążków prawdy (Logos Spermatikos) zarówno w religiach, jak i systemach filozoficznych. Zainteresowanie innymi religiami podjęte było przez teologów Średniowiecza oraz czasów nowożytnych (zwłaszcza po nastaniu epoki odkryć geograficznych) i współczesnych.

Teologią religii zajmują się obecnie głównie badacze z kręgu kultury Zachodu (chrześcijaństwa). Badacze spoza tego kręgu stanowią wciąż „wyjątek” (np. Martin Buber „reprezentujący “ judaizm, czy hindusita Servepalii Radhakrishnan). W zależności od teologii (protestanckiej lub katolickiej), istnieje propozycja uprawiania teologii religii, wyznaczona przez teologię dialektyczną Karla Bartha (który deprecjonował inne niż chrześcijaństwo religie) lub też teologię dopełnienia Hansa Ursa von Balthasara i Raimona Panikkara (którzy twierdzili, iż chrystianizm jest zwieńczeniem, swoistą „ostateczną pieczęcią" wszystkich religii świata).

Teologia religii wyjaśnia oraz interpretuje treści innych religii w świetle wiary i objawienia własnej religii. Według jednej z definicji jest nauką badająca wartość zbawczą innych religii w świetle własnego objawienia. Nauka ta czerpie „materiał” z religioznawstwa empirycznego. Dokonuje następnie ocen wartościujących oraz normatywnych.

W katolickiej teologii religii wyróżnić można różne nurty, w tym skrajny, ekskluzywistyczny, dziś przyjmowany przez tzw. tradycjonalistów, integrystów katolickich, którym obca jest idea i pragmatyka dialogu intereligijnego. Religie niechrześcijańskie traktowane są jako „antytezy” chrześcijaństwa. Innym jest nurt inkluzywistyczny. Nie wyraża on tendencji relatywistycznych, wg których wszystkie religie (i ich założycie) są sobie równe (równi), jednakowo zbawcze. Inkluzywizm oznacza tu włączenie religii niechrześcijańskich w pedagogię zbawienia, wg której są one soteriologiczną drogą, wiodącą ostatecznie do Jezusa Chrystusa, jedynego Pana i Zbawcę.

W kontekście powyższej ogólnej refleksji wprowadzającej spójrzmy na dzieło Zbigniewa Kubackiego SI pt. Wprowadzenie do teologii religii. Wpierw jednak przedstawmy autora.

Jezuita - ojciec prof. dr hab. Zbigniew Józef Kubacki jest teologiem specjalizującym się w zakresie teologii dogmatycznej oraz teologii religii. W Papieskim Wydziale Teologicznego w Warszawie - Collegium Bobolanum (którego do 2018 r. był rektorem) prowadzi od szeregu lat działalność naukowo-badawczą w Katedrze Teologii Fundamentalnej i Dogmatycznej. W 1999 r. na Wydziale Teologicznym Towarzystwa Jezusowego „Centre Sèvres” w Paryżu uzyskał doktorat nauk teologicznych na podstawie dysertacji pt. La nouveauté de Dieu. La question de Dieu dans la christologie de Joseph Moingt. W 2006 r. został doktorem habilitowanym nauk teologicznych w zakresie teologii dogmatycznej. Rozprawa habilitacyjna pt. Jedyność Jezusa Chrystusa. O jedyności i powszech- 
ności zbawczej Jezusa Chrystusa w kontekście chrześcijańskich teologii religii stanowiła zwieńczenie jego dotychczasowej pracy naukowo-badawczej, jak również wyznaczyła dalsze kierunki eksploracji. W 2018 r. został profesorem tytularnym nauk teologicznych. W postępowaniu o tytuł profesora ważna była ocena osiągnięć naukowych, w tym tzw. książki profesorskiej pt. Kościół, religie i zbawienie. O jedyności i powszechności zbawczej Kościoła oraz zbawczej roli religii niechrześcijańskich (Kraków 2016, ss. 681).

Główny nurt badań naukowych Z. Kubackiego SI wyznacza właśnie teologia religii. Zajmuje się on głównie dylematami teologii religii i ich odniesieniem do możliwości lub niemożliwości dialogu międzyreligijnego. Prowadzone przezeń badania można też umieścić w polu zainteresowań teologii fundamentalnej (dawnej apologetyki), w której istotnym był zawsze „Traktat o religii”. Stanowił ten traktat „punkt wyjścia” do uwiarygodnienia chrześcijaństwa jako religii objawionej przez Boga, a Kościoła jako Bosko-ludzkiej instytucji założonej przez Jezusa Chrystusa.

Dziełami zwartymi i jednocześnie kluczowymi z zakresu teologii religii są wskazane wyżej pozycje książkowe: Jedyność Jezusa Chrystusa... oraz Kościót, religie i zbawienie... Łączna objętość tych dwóch „monumentalnych” dzieł wynosi ponad 1200 stron! Do tychże dwóch książek dołącza się kolejna, obecnie prezentowana pt. Wprowadzenie do teologii religii (ss. 307). W nurcie tym sytuują się również artykuły, np.: Opcje pluralistyczne w teologii religii, „Studia Theologica Varsaviensia" 47(2009) nr 2, s. 111-138; Chrystus kosmiczny w kontekście chrześcijańskiej teologii religii, w: L. Csontos, D. Kielak, Z. Plasnienkowa (red.), Wiara i kultura miejscem dialogu, Warszawa 2013, s. 166-187; Zbawienie i zbawiciele w pluralistycznej teologii religii, „Studia Bobolanum” $2014 \mathrm{nr} 3$.

Strukturę książki Wprowadzenie do teologii religii stanowią cztery rozdziały poprzedzone Wykazem skrótów oraz Wstępem. Każdy rozdział (mający szereg punktów) kończy się obszernym, rozbudowanym podsumowaniem.

Rozdział 1. - „Historia i interpretacja formuły Poza Kościołem nie ma zbawienia” (s. 6-94) przybliżył „początki patrystyczne” kiedy aktualnym stało się pytanie o Jezusa Chrystusa i Kościół oraz jednocześnie o zbawienie człowieka. Skupił się na „Średniowieczu” i jego soborach, a także na nauczaniu św. Tomasza z Akwinu. Następnie rozdział ten przybliżył okres nowożytny, a w nim naświetlił stanowisko wobec innych religii Szkoły Dominikańskiej w Salamance oraz jezuitów z Kolegium Rzymskiego. Wskazał na kryzys jansenistyczny. Omówił nauczanie Kościoła w XIX i XX wieku do Soboru Watykańskiego II. Tu „wypunktował” dokumenty Magisterium Kościoła oraz zaprezentował podręczniki teologii neoscholastycznej. Wskazał na prekursorów soborowej eklezjologii oraz soborowej teologii religii. W podsumowaniu tego rozdziału Z. Kubacki podkreślił prawdę o konieczności Jezusa Chrystusa i Kościoła do zbawienia oraz omówił teologiczny status religii niechrześcijańskich. 
Rozdział 2. - „Jezus Chrystus a zbawienie w teologii posoborowej” (s. 95-154) skupił się na „Jedyności i powszechności zbawczej Jezusa Chrystusa w ujęciu inkluzywistycznym". Rozwijając ten temat zaakcentował kolejno: stanowisko Vaticanum II wobec innych religii; , intuicje” i stwierdzenia Encyklika Redemptoris missio Jana Pawła II; konstatacje Deklaracji Dominus Iesus ogłoszonej w 2000 r. przez Kongregację Nauki Wiary, a podpisanej przez kard. Josepha Ratzingera; dokument Międzynarodowej Komisji Teologicznej pt. Chrześcijaństwo i religie z 1996 r.. W dalszej części tego rozdziału autor wymienił wybranych teologów opcji inkluzywistycznej i przeprowadził analizę ich poglądów (Karl Rahner SI, Claude Geffré, Gavin D’Costa, Jacques Dupuis SI; Ireneusz Sławomir Ledwoń OFM). Naświetlił „wizję" jedyności i powszechności zbawczej Jezusa Chrystusa w ujęciu pluralistycznym analizując jednocześnie poglądy przedstawicieli tego nurtu teologii religii (John Hick, Raimon Panikkar, Paul F. Knitter, Schubert M. Ogden, Roger Haight SI).

W rozdziale 3. - „Kościół a zbawienie w teologii posoborowej” (s. 155-218) omówiono konstatacje Magisterium Kościoła z zakresu teologii religii, wyłożone w dokumentach: wskazanych wcześniej Encyklice Redemptoris misio oraz Deklaracji Dominus Iesus oraz w Katechizmie Kościoła katolickiego. Po zaprezentowaniu stanowiska Urzędu Nauczycielskiego Kościoła autor naszkicował treść dokumentów Międzynarodowej Komisji Teologicznej. Skupił się na poruszanych $\mathrm{w}$ nich wybranych zagadnieniach z eklezjologii. Przedstawił problematykę ujętą w „haśle”: chrześcijaństwo i religie. Podjął temat ważny nie tylko w perspektywie refleksji o religiach niechrześcijańskich, którym jest nadzieja zbawienia dla dzieci zmarłych bez chrztu, ale też w szerszym odniesieniu - ekumenicznym oraz dotyczącym niewierzących w Boga. Na koniec przedstawił „katalog” teologów soborowych (Gérard Philips, Yves Congar OP, Henri de Lubac SI, J. Ratzinger, K. Rahner SI) oraz posoborowych (Francis A. Sullivan SI, Jean-Marie Pasquier, J. Dupuis SI). Omówił nadto Szkołę Lubelską promującą - w ślad za jej założycielem Marianem Ruseckim - tzw. objawieniową teorię religii, ostro krytykującą tezę o istnieniu religii naturalnych. W podsumowaniu Z. Kubacki SI wskazał na relacje między Kościołem i zbawieniem. Podkreślił rolę Kościoła jako przyczyny celowej zbawienia oraz naświetlił Misterium Eucharystii.

$\mathrm{W}$ rozdziale 4. - „Religie niechrześcijańskie a zbawienie w teologii posoborowej" (s. 219-304) ponownie autor skupił się na wybranych dokumentach oraz poglądach wcześniej przedstawionych teologów. Przeprowadził jednakże refleksję koncentrując się na innym aspekcie tematu. Wskazał tu na wypowiedzi doktrynalne Magisterium Kościoła zawarte w encyklikach Jana Pawła II (Dominum et Vivificantem, Redemptoris misio) oraz Deklaracji Dominus Iesus. Ponownie „zauważył” dokument Międzynarodowej Komisji Teologicznej. Wymienił teologów opcji inkluzywistycznej, którzy akcentują pluralizm religijny de facto (Karl Josef Becker SI, J. Ratzinger, G. D'Costa, Joseph Moingt SI oraz środowisko tomistyczne), jak również teologów tej samej opcji, głoszą- 
cych tezę o pluralizmie religijnym de iure (K. Rahner SI, J. Dupuis SI, Claude Geffré, Michael A. Barnes SI, I.S. Ledwoń OFM). W podsumowanie wyciągnął wnioski dotyczące kwestii religii a zbawienia. Omówił specyfikę islamu oraz innych religii niechrześcijańskich. Wskazał na nieredukowalność judaizmu oraz w końcu na wyjątkowość chrześcijaństwa. Rozdział ten i w ogóle książkę zamknął pytaniem: „Czy teologia komparatywna jest alternatywą dla teologii religii?”

Z. Kubacki SI w pierwszych zdaniach Wstępu do książki wskazał na przedmiot swojego studium: „Chrześcijańska teologia religii, choć jest stosunkowo młodą wyodrębnioną dyscypliną teologiczną, to zagadnienia, którymi się zajmuje, są tak stare jak chrześcijaństwo. Sam termin pojawił się w latach pięćdziesiątych i sześćdziesiątych XX wieku. Przedmiotem tej dyscypliny jest badanie religii niechrześcijańskich w świetle objawienia Boga w Jezusie Chrystusie, a zasadnicze pytanie dotyczy zarówno możliwości zbawienia dla niechrześcijan, jak i zbawczej roli religii niechrześcijańskich w zbawieniu ich wyznawców. Na przestrzeni wieków wykształciły się rożne odpowiedzi na powyższe pytania. Z początkiem lat osiemdziesiątych przyjęło się wyróżniać trzy zasadnicze paradygmaty teologiczne: ekskluzywizm, inkluzywizm i pluralizm" ( s. 9).

Ekskluzywizm ogranicza perspektywę zbawienie tylko do kręgu wierzących jurydycznie związanych z Kościołem. „Posiłkuje się” przy tym koronnym argumentem - aksjomatem przypisywanym św. Cyprianowi z Kartaginy (zm. 258): Extra Ecclesiam nulla salus („Poza Kościołem nie ma zbawienia”). Autor dokonując analizy tego stwierdzenia uwypuklił zmianę jego sensu. Przez wieki odnosiło się ono do tych, którzy zarówno instytucjonalnie jak i doktrynalnie odłączyli się od Kościoła katolickiego, tj. heretyków i schizmatyków. Nigdy w znaczeniu „pierwotnym” nie mówiło o niechrześcijanach. Nurt ekskluzywistyczny występuje - co wyżej już zauważono - w teologii protestanckiej (dziś głównie w Stanach Zjednoczonych). „(..) literalna i ekskluzywistyczna interpretacja tej formuły - stwierdza Z. Kubacki SI - została odrzucona w Kościele katolickim przez Papieża Klemensa XI w 1713 r. przy okazji kryzysu jansenistycznego, co następnie potwierdzono w innych oświadczeniach Magisterium Kościoła katolickiego w XIX i XX wieku, a czego zwieńczeniem był Sobór Watykański II” (s. 9).

Inkluzywizm natomiast od czasów Soboru Watykańskiego II wyraża oficjalne stanowisko Kościoła katolickiego wobec religii niechrześcijańskich. Prekursorem tego nurtu był przywołany już wcześniej K. Rahner SI, głoszący teorię „anonimowego chrześcijaństwa”, wg której każdy człowiek, bez względu na religię, którą wyznaje, jest usprawiedliwiony przez łaskę Bożą, a zatem może osiągnąć zbawienie. Zwolennicy inkluzywizmu twierdzą, iż perspektywa zbawienia jest otwarta dla każdego człowieka, bowiem zostało ono wysłużone przez Jezusa Chrystusa, który złożył ofiarę ze Swojego życia na krzyżu - umarł i zmartwychwstał za całą ludzkość, ludzi wszystkich kultur i religii. Łaska wysłużona przez Syna Bożego, mocą tajemniczej obecności w świecie i człowieku Ducha 
Świętego i mocą Jego działania, ,jest dostępna wszystkim ludziom, nawet tym, którzy nigdy o Jezusie nie słyszeli i nie usłyszą" (s. 10).

We Wprowadzeniu do teologii religii omówione zostało rozumienie i interpretacja jedyności i powszechności zbawczej: Jezusa Chrystusa oraz Kościoła, a także zbawczej roli religii niechrześcijańskich w odwiecznym planie Boga wobec ludzkości. Rangę tych prawd podkreśla wspomniana wyżej Deklaracja Dominus Iesus. Z. Kubacki w dziele swoim stawia fundamentalne pytanie, takie same, które apostołowie kierowali do Jezusa Chrystusa, swojego Pana: „Kto może być zbawiony?" (Mt 19,25) (s. 12).

Przez wieki teologia zainteresowana była perspektywą, możliwością zbawienia niechrześcijan, a zatem tych, którzy są poza Kościołem. Bardzo często im odmawiano tej perspektywy. Dziś aktualnym jest inne pytanie: „(..) czy i w jaki sposób różne tradycje religijne mogą mieć pozytywne znaczenie w Bożym planie zbawienia. Czy teologicznie słuszne jest stwierdzenie, że tak jak Kościół Chrystusowy jest $<<$ drogą zbawienia $>$ dla chrześcijan, tak samo inne religie są podobnymi $<<$ drogami zbawienia $>$ dla swoich wyznawców? Czy w epoce dialogu międzyreligijnego można jeszcze mówić o konieczności Kościoła do zbawienia? Czy <<świętym pismom>> innych religii możemy nadać statut słowa Bożego, podobnie jak dla chrześcijan stanowią je pisma Starego i Nowego Testamentu? Czy możemy, jako chrześcijanie, uznać, że <<ostateczna Rzeczywistość $>$, o której na różne sposoby mówią wszystkie religie, jest tak radykalnie transcendentna, że żadna $\mathrm{z}$ nich nie jest w stanie w pełni jej wyrazić, co oznaczałoby, iż jej wszystkie religijne wyrażenia wbrew pozorom nie są sobie przeciwstawne (np. Bóg osobowy i Bóg bezosobowy), lecz komplementarne? Co jednak z tradycyjnym chrześcijańskim roszczeniem twierdzącym, że Jezus Chrystus jest pełnym i ostatecznym Objawieniem Boga Ojca (Kto Mnie widziat, widział i Ojca [J 14,9])? Co myśleć o tradycyjnym wyznaniu wiary, widzącym $\mathrm{w}$ Jezusie pełne i ostateczne objawienie Boga oraz jedynego i powszechnego Zbawiciela wszystkich ludzi? Co z tradycyjnym nauczaniem mówiącym o konieczności Kościoła do zbawienia?” (s. 13). Z. Kubacki SI z dociekliwością badacza, którego nie satysfakcjonują „poprawne politycznie” (religijnie) odpowiedzi wnika w nauczanie Magisterium i teologii (teologów), by tamże znaleźć odpowiedź.

Autor omawianej pracy przedstawił poglądy dotyczące wskazanych wyżej dogmatycznych kwestii a traktujące o jedyności i powszechności zbawczej: Jezusa Chrystusa oraz Kościoła, a także zbawczej roli religii niechrześcijańskich w odwiecznym planie Boga wobec ludzkości. Poznanie ich stanowi solidne przygotowanie do podjęcia i prowadzenia dialogu międzyreligijnego, szczególnie do uczestnictwa w jednej jego formie, którą jest dialog teologiczny (określany również jako dialog ekspertów, czy specjalistów).

Studium dzieła Wprowadzenie do teologii religii prowadzić może do wyciągnięcia poniższych wniosków. Kościół nie zmienił doktryny soteriologicznej. Nie 
przestał głosić, na przekór różnym teoriom sytuującym się w nurcie pluralizmu teologicznego (uprawomocniającego istnienie różnych soteriologicznych dróg i ścieżek, w tym bez Jezusa, czy na przekór Jezusowi), iż do zbawienia człowieka konieczny jest Jezus Chrystus oraz Jego Kościół. „Puentując obecne rozważania nad historią i interpretacją adagium $<<$ Poza Kościołem nie ma zbawiania $>$, możemy stwierdzić, - zaznacza Z. Kubacki SI - że w aksjomacie tym wyrażenie „poza Kościołem” winno być rozumiane w sensie $<<$ bez niego $>$, pojęte jako <<całkowicie bez niego > . Extra Ecclesiam nulla salus oznacza zatem: Sine Ecclesia nulla salus - bez Kościoła nie ma zbawienia (s. 92).

Nie można zaakceptować poglądów teologów będących zwolennikami tzw. opcji pluralistycznej w rozumieniu zbawienia. Kontrargumenty podaje zarówno nauczanie Nowego Testamentu, jak i wielowiekowa Tradycja oraz Magisterium Kościoła. Poddawanie w wątpliwość prawdy wiary o jedyności i powszechności zbawczej Jezusa Chrystusa, a nawet jej negowanie jest po prostu błędem. Co więcej, Kościół ma wymiar uniwersalistyczny. Obejmuje wszystkich ludzi sprawiedliwych, by proklamować im zbawienie. A nawet jeśli „głoszenie” Dobrej Nowiny nie jest możliwe - dodajmy, np. z racji politycznych - to przecież nikt nie jest dla Kościoła obojętny.

Kościół jest od początku istnienia przyczyną celową zbawienia wszystkich ludzi. Człowiek dochodził doń dzięki „łasce Chrystusowej” (gratia Christi), którą można - jak uważa Z. Kubacki SI - określić też jako „łaską eklezjalną” (gratia ecclesialis); „(...) była [ona] i jest udzielana ze względu na Kościół i przyporządkowuje do Kościoła także te osoby, które zostały zbawione przez Jezusa Chrystusa poza Kościołem" (s. 209-210).

Bardzo ważny wniosek z lektury dzieła Wprowadzenie do teologii religii dotyczy wyjątkowości chrześcijaństwa. Wcześniejsza, przedsoborowa teologia mówiła o absolutnym charakterze chrześcijaństwa. Dziś słowo „absolutny” rodzić może niepokojące skojarzenia (np. absolutny, jako bezwzględny, czy totalny). Oryginalność chrześcijaństwa jako religii wyjątkowej zasadza się „na absolutności Jezusa Chrystusa i wynikającej z niej szczególnej roli Kościoła jako powszechnego sakramentu zbawienia; na uznaniu swojej świętości i grzeszności oraz potrzebie nieustannego oczyszczenia; na dialogicznym wymiarze zawierającym się $\mathrm{w}$ sformułowaniu $<<$ nie bez drugiego $>$; oraz na misyjności wypływającej z nakazu Chrystusa" (s. 282-283).

Chrześcijaństwo jest wyjątkowe, bowiem jego Założyciel jest osobą wyjątkową - prawdziwym Bogiem-Człowiekiem, który przez Wcielenie upodobnił się do każdej osoby ludzkiej i każdej osobie - bez wyjątku - ukazał pespektywę zbawienia mocą Swojego Imienia, mocą woli Boga w Trójcy Jedynego.

Lektura dzieła Wprowadzenie do teologii religii nie jest łatwa. I dobrze! Zachęca bowiem do skupienia się, a także rozważania dylematów w nim nie tyle rozwiązanych i „zapieczętowanych”, ile wciąż domagających się prowadzenia dalszej refleksji. 